\title{
Contribution of preterm delivery to perinatal mortality
}

\author{
R W RUSH, M J N C KEIRSE, PAMELA HOWAT, J D BAUM, ANNE B M ANDERSON, \\ A C TURNBULL
}

British Medical fournal, 1976, 2, 965-968

\begin{abstract}
Summary
A detailed retrospective analysis was made of the records of 486 preterm infants, who accounted for $5 \cdot 1 \%$ of all births during 1973 and 1974 . Whereas preterm delivery did not contribute to perinatal mortality in terms of stillbirth, it outweighed all other causes in terms of early neonatal deaths. Preterm birth was responsible for $85 \%$ of the early neonatal deaths not due to lethal congenital deformities. Early neonatal mortality rates were closely linked both to gestational age and birth weight and to the reason for preterm birth. Early neonatal mortality was high (97 per 1000) when preterm labour was spontaneous, whether or not associated with maternal or fetal disease or with multiple pregnancy, but low (27 per 1000) when preterm delivery was elective. Preventing spontaneous preterm labour would considerably reduce neonatal mortality in our community.
\end{abstract}

\section{Introduction}

There is general agreement that delivery too early in pregnancy is a major cause of perinatal mortality, though its real influence is difficult to define. ${ }^{1}$ There are several reasons for this lack of information. Confusion has arisen because the term prematurity

\footnotetext{
Nuffield Department of Obstetrics and Gynaecology, University of Oxford, John Radcliffe Hospital, Oxford OX3 9DU

R W RUSH, MB, MRCOG, research medical officer

M J N C KEIRSE, MD, DPHIL, research medical officer

ANNE B M ANDERSON, MD, PHD, university lecturer

A C TURNBULL, MD, FRCOG, Nuffield professor of obstetrics and gynaecology

Department of Paediatrics, University of Oxford, John Radcliffe Hospital, Headington, Oxford OX3 9DU

PAMELA HOWAT, RGN, SCM, research sister

J D BAUM, MRCP, MD, clinical reader
}

was used initially to denote infants of $2500 \mathrm{~g}$ or less ${ }^{2}$ and later to denote infants born three weeks or more before term. ${ }^{3}$ There is now wide agreement that the term prematurity should no longer be used and that babies should be described in terms of either birth weight or gestational age. ${ }^{4-6}$ Infants born before the onset of the 37th week of pregnancy-that is, three weeks or more before the expected date of delivery-are now described as preterm.?

There are several problems associated with any analysis of perinatal mortality in relation to preterm birth. Most studies on preterm infants have used birth weight as the criteria and studied infants of $2500 \mathrm{~g}$ or less, ${ }^{8}{ }^{9}$ yet more than $40 \%$ of them are born at 38 weeks or later. ${ }^{10}$ Although gestational age is the criterion we want to use, its calculation based on the date of the last menstrual period is reliable only in some cases. Furthermore, while some preterm labours occur for no apparent reason, others are associated with causal factors such as multiple pregnancy, fetal abnormality, maternal infection, or antepartum haemorrhage, which themselves may be responsible for a substantial proportion of perinatal loss. Preterm delivery may also be due to deliberate obstetric intervention because pregnancy is complicated by such factors as inadequate fetal growth, rhesus isoimmunisation, or severe pre-eclampsia.

Since we know of no study where all these indices have been taken into account, we undertook the present analysis to determine the association between preterm delivery and perinatal mortality in our community by correlating the outcome for the baby not only with gestational age and birth weight but also with possible causal factors associated with preterm birth such as multiple pregnancy and maternal or fetal complications.

\section{Patients and methods}

A detailed retrospective study was made of the records of 486 infants delivered before the onset of the 37th week of gestation (preterm) at the John Radcliffe Hospital, Oxford, from 1 January 1973 to 31 December 1974. During these two years 9458 patients were delivered $(90 \%$ in the consultant unit and $10 \%$ in the general practitioner unit)-9372 with a single and $86(0.9 \%)$ with a twin pregnancy. The $\mathbf{4 8 6}$ preterm infants accounted for $5.1 \%$ of all deliveries in this period.

Gestational age at delivery was calculated for stillbirths from the last menstrual period and for liveborn infants from the last menstrual 
period combined with paediatric assessment at birth using the criteria of Farr $e t$ al ${ }^{11}$ and Dubowitz et al. ${ }^{12}$ The percentiles for birth weight of infants delivered before 32 weeks were calculated from the figures reported by Babson et $\mathrm{al}^{13}$ and for those born at 32 weeks or more from the data of Tanner and Thomson. ${ }^{14}$ Infants with a birth weight below the 5th percentile for gestational age were classified as growth retarded. ${ }^{15}$

Stillbirth was defined as fetal death occurring between 28 weeks of pregnancy and delivery. Early neonatal death was defined as the death of any liveborn baby in the first week of life irrespective of its gestational age

\section{Results}

During 1973 and 1974 the perinatal mortality rate for the hospital was 15.5 per 1000 (table I). This was made up of a stillbirth rate of 8.9 per 1000 and an early neonatal death rate of 6.6 per 1000 . One-third of all perinatal deaths, however, were due to a lethal congenital abnormality, and these were excluded from the analysis.

TABLE I-Perinatal mortality at fohn Radcliffe Hospital, Oxford, in 1973 and 1974 (total births $=9544)$

\begin{tabular}{|c|c|c|c|}
\hline $\begin{array}{l}\text { Category and } \\
\text { gestational } \\
\text { age }\end{array}$ & Stillbirths & $\begin{array}{c}\text { Early } \\
\text { neonatal } \\
\text { deaths }\end{array}$ & $\begin{array}{l}\text { Perinatal } \\
\text { deaths }\end{array}$ \\
\hline $\begin{array}{l}\text { No of infants without lethal } \\
\text { deformities: } \\
<37 \text { weeks } \\
\geqslant 37 \text { weeks } \\
\text { No of infants with lethal } \\
\text { deformities: } \\
<37 \text { weeks } \\
\geqslant 37 \text { weeks }\end{array}$ & $\begin{array}{l}36^{59(69 \cdot 4 \%)} \\
23^{26(30 \cdot 6 \%)} \\
14^{26}\end{array}$ & $\begin{array}{l}34^{40(63 \cdot 5 \%)} \\
7^{23(36 \cdot 5 \%)} \\
16\end{array}$ & $\begin{array}{l}70^{99(66 \cdot 9 \%)} \\
29 \\
21 \\
28\end{array}$ \\
\hline Total & $85(100 \%)$ & $63(100 \%)$ & $148(100 \%)$ \\
\hline Rate per 1000 total births & 8.9 & 6.6 & $15 \cdot 5$ \\
\hline
\end{tabular}

\section{PRETERM STILLBIRTHS}

Thirty-six stillbirths without lethal deformity occurred between the 28th and the onset of the 37th week of pregnancy and accounted for $61 \%$ of normally formed stillbirths (table I). Most of these preterm stillbirths were macerated and only nine could be possibly classified as intrapartum deaths, although all had occurred before admission to hospital in labour. Seven of the nine deaths were due to abruptio placentae, and only two were associated with spontaneous labour: one with prolapse of the cord at 34 weeks, the other occurring for no known reason at 28 weeks in a patient with a history of recurrent abortion and a cervical suture in situ.

\section{PRETERM EARLY NEONATAL DEATHS}

Of the 40 early neonatal deaths not due to lethal abnormality, 34 $(85 \%)$ occurred in infants with a gestational age of less than 37 weeks and more than 22 weeks (table I), giving a preterm early neonatal death rate in these "normal" infants of 79.3 per 1000 live births, in contrast to a rate of 0.66 per 1000 if delivery occurred at 37 weeks or more. The gestational age and weight at birth of these 34 preterm infants who died in the first week of life are -shown in table II. As might be expected, early neonatal mortality rates were high in infants weighing less than $1500 \mathrm{~g}$ delivered before the 32nd week of pregnancy but dropped sharply above that weight and gestational age; all infants who weighed $2250 \mathrm{~g}$ or more at birth survived, and there were only four early neonatal deaths among 309 normally formed infants with a gestational age of greater than 33 weeks. Since there were several reasons for the preterm delivery of these infants, we made a detailed study to determine the influence of possible aetiological factors for preterm delivery on early neonatal mortality.

All preterm deliveries of infants born alive without lethal deformity after 22 weeks' gestation were divided into four groups according to whether the birth was associated with $(a)$ spontaneous labour without apparent maternal or fetal complications; $(b)$ spontaneous labour with maternal or fetal complications including growth retardation; $(c)$ multiple pregnancy; or $(d)$ deliberate intervention by the obstetrician. The total number of pregnancies along with the neonatal deaths in each of these categories are given in table III.

TABLE III-Preterm delivery of infants born alive without lethal deformity: numbers of pregnancies, births, and early neonatal deaths related to type of preterm delivery

\begin{tabular}{|c|c|c|c|c|}
\hline $\begin{array}{c}\text { Type of preterm } \\
\text { delivery }\end{array}$ & $\left|\begin{array}{c}\text { No }(\%) \text { of } \\
\text { pregnancies }\end{array}\right|$ & $\begin{array}{l}\text { No of } \\
\text { live births }\end{array}$ & $\begin{array}{l}\text { No (\%) of } \\
\text { deaths }\end{array}$ & $\begin{array}{c}\text { Mortality } \\
\text { rate (per } \\
1000 \text { live } \\
\text { births) }\end{array}$ \\
\hline $\begin{array}{l}\text { Spontaneous labour of unknown } \\
\text { cause }\end{array}$ & $148(38)$ & 148 & $12(35)$ & $81 \cdot 1$ \\
\hline Spontaneous labour with maternal & $96(24)$ & 96 & $10(29)$ & $104 \cdot 2$ \\
\hline $\begin{array}{l}\text { Multiple pregnancy } \\
\text { Elective* }\end{array}$ & $\begin{array}{r}40(10) \\
109(28)\end{array}$ & $\begin{array}{r}76 \\
109\end{array}$ & $\begin{array}{l}9(27) \\
3(9)\end{array}$ & $\begin{array}{r}118 \cdot 4 \\
27 \cdot 5\end{array}$ \\
\hline Total & $393(100)$ & 429 & $34(100)$ & $79 \cdot 3$ \\
\hline
\end{tabular}

*Includes 57 caesarean sections and 52 induced labours.

Spontaneous labour of unknown cause-Preterm labour occurring for no apparent reason and without associated fetal growth retardation accounted for $38 \%$ of all preterm deliveries and $35 \%$ of all preterm early neonatal deaths (table III). No infant in this group born at a gestational age of less than 28 weeks and with a birth weight of less than $1250 \mathrm{~g}$ survived (table IV). From 28 weeks onwards survival was the rule, and only four out of 140 infants died, all as a result of intraventricular haemorrhage associated with hyaline membrane disease.

Spontaneous labour associated with complications-Spontaneous preterm labour was associated with fetal growth retardation or maternal disorders, or both, in 96 cases, accounting for $24 \%$ of all preterm deliveries. Antepartum haemorrhage was the most common finding in this group, followed by fetal growth retardation, cervical incompetence, and hypertension (table V). More than one pathological factor was present in several cases, but only the predominant factors are listed in table V. There were 10 neonatal deaths in this group, giving an early neonatal mortality rate of 104 per 1000 , which is only slightly higher than that after spontaneous preterm labour without associated disorders (81 per 1000). When early neonatal mortality in

TABLE II-Number of preterm liveborn infants without lethal deformity, number of early neonatal deaths (in parentheses), and early neonatal mortality rates in relation to gestational age and birth weight

\begin{tabular}{|c|c|c|c|c|c|c|c|c|c|c|c|c|}
\hline \multirow{2}{*}{$\begin{array}{c}\text { Gestational } \\
\text { age } \\
\text { (weeks) }\end{array}$} & \multicolumn{9}{|c|}{ Birth weight (g) } & \multirow{2}{*}{$\begin{array}{c}\text { No of } \\
\text { infants }\end{array}$} & \multirow{2}{*}{$\begin{array}{l}\text { No of } \\
\text { deaths }\end{array}$} & \multirow{2}{*}{$\begin{array}{c}\text { Mortality } \\
\text { rate } \\
\text { (per 1000) }\end{array}$} \\
\hline & $<750$ & -999 & -1249 & -1499 & -1749 & -1999 & -2249 & -2449 & $\geqslant 2500$ & & & \\
\hline $\begin{array}{c}23-25 \\
26-27 \\
28-29 \\
30-31 \\
32-33 \\
34-35 \\
36\end{array}$ & $\begin{array}{l}3(3) \\
3(3) \\
1\end{array}$ & $\begin{array}{l}6(4) \\
1 \\
1(1)\end{array}$ & $\begin{array}{r}1(1) \\
3(2) \\
12(5) \\
4 \\
1 \\
1\end{array}$ & $\begin{array}{r}11(4) \\
9(3) \\
9(1) \\
5\end{array}$ & $\begin{array}{l}2 \\
7 \\
9 \\
8 \\
3\end{array}$ & $\begin{array}{l}2 \\
20(1) \\
20(1) \\
11(1)\end{array}$ & $\begin{array}{l}11 \\
36 \\
27\end{array}$ & $\begin{array}{r}5 \\
40 \\
39\end{array}$ & $\begin{array}{l}29 \\
89\end{array}$ & $\begin{array}{r}4 \\
12 \\
26 \\
23 \\
55 \\
139 \\
170\end{array}$ & $\begin{array}{l}4 \\
9 \\
9 \\
5 \\
3 \\
3 \\
1\end{array}$ & $\begin{array}{r}1000 \\
750 \\
346 \\
217 \\
54.5 \\
21.6 \\
5.9\end{array}$ \\
\hline No of infants & 7 & 8 & 22 & 34 & 29 & 53 & 74 & 84 & 118 & 429 & & \\
\hline No of deaths & 6 & 5 & 8 & 8 & 2 & 3 & 2 & 0 & 0 & & 34 & \\
\hline$\overline{\text { Mortality rate (per 1000) }}$ & 857 & 625 & 364 & 235 & $69 \cdot 0$ & $56 \cdot 6$ & $27 \cdot 0$ & & & & & $79 \cdot 3$ \\
\hline
\end{tabular}


TABLE IV-Spontaneous preterm labour of unknown cause: number of liveborn infants without lethal deformity and number of early neonatal deaths (in parentheses) according to gestational age and birth weight

\begin{tabular}{|c|c|c|c|c|c|c|c|c|c|c|c|}
\hline \multirow{2}{*}{$\begin{array}{c}\text { Gestational } \\
\text { age } \\
\text { (weeks) }\end{array}$} & \multicolumn{9}{|c|}{ Birth weight (g) } & \multirow{2}{*}{$\begin{array}{c}\text { No of } \\
\text { infants }\end{array}$} & \multirow{2}{*}{$\begin{array}{l}\text { No of } \\
\text { deaths }\end{array}$} \\
\hline & $<750$ & -999 & -1249 & -1499 & -1749 & -1999 & -2249 & -2449 & $\geqslant 2500$ & & \\
\hline $\begin{array}{c}23-25 \\
26-27 \\
28-29 \\
30-31 \\
32-33 \\
34-35 \\
36\end{array}$ & $\begin{array}{l}3(3) \\
1(1)\end{array}$ & $2(2)$ & $\begin{array}{l}1(1) \\
1(1) \\
3(1) \\
1\end{array}$ & $\begin{array}{l}3 \\
1 \\
4\end{array}$ & $\begin{array}{l}2 \\
4(1) \\
2 \\
1\end{array}$ & $\begin{array}{l}2 \\
9 \\
9(1)\end{array}$ & $\begin{array}{l}3 \\
13(1) \\
10\end{array}$ & $\begin{array}{r}2 \\
15 \\
14\end{array}$ & $\begin{array}{l}11 \\
31\end{array}$ & $\begin{array}{r}4 \\
4 \\
8 \\
8 \\
20 \\
49 \\
55\end{array}$ & $\begin{array}{l}4 \\
4 \\
1 \\
1 \\
0 \\
2 \\
0\end{array}$ \\
\hline No of infants & 4 & 2 & 6 & 8 & 9 & 20 & 26 & 31 & 42 & 148 & \\
\hline No of deaths & 4 & 2 & 3 & 0 & 1 & 1 & 1 & 0 & 0 & & 12 \\
\hline
\end{tabular}

TABLE V-Predominant maternal and fetal disorders associated with spontaneous preterm labour in liveborn infants without lethal deformity

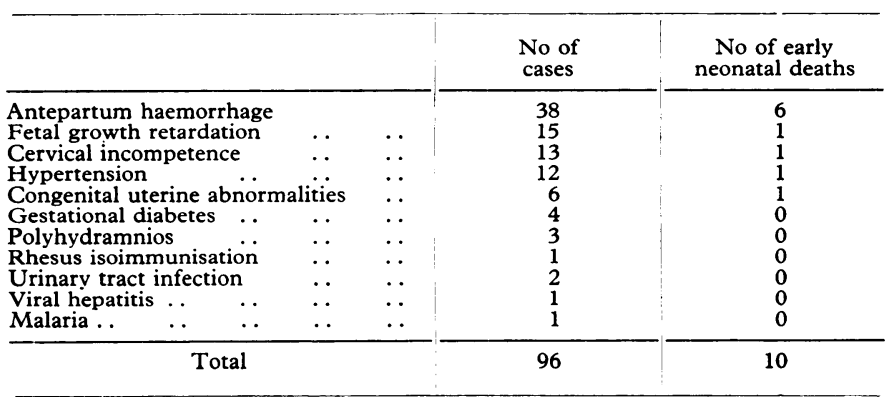

this group was related to gestational age and birth weight, however, a pattern emerged different from that seen in spontaneous preterm labour of unknown cause, the relation between early neonatal mortality and gestational age and birth weight being less pronounced (table VI). For example, when preterm delivery was not associated with disease none of the four infants delivered at 26-27 weeks survived, whereas three of the five infants born at this early age in the group with associated complications survived. In all five cases preterm delivery was associated with antepartum haemorrhage.

Multiple pregnancy-The incidence of preterm delivery in multiple pregnancies (all twins) was 12 times higher than that seen in single pregnancies $(47 \cdot 1 \% v 3 \cdot 8 \%$ ). Forty twin pregnancies ended before the 37th week of gestation, and they accounted for 76 liveborn infants without lethal deformities. There were nine early neonatal deaths (118 per 1000) in this category, all of which occurred in infants born before 32 weeks' gestation with a birth weight less than $1500 \mathrm{~g}$ (table VII). These infants were born of six mothers, three of whom lost both babies.

Deliberate obstetric intervention-In 109 cases preterm delivery was the result of deliberate obstetric intervention, by elective caesarean section in 57 and after induction of labour in 52 cases. Reasons for intervention are listed in table VIII. This group accounted for $28 \%$ of all preterm deliveries but for only $9 \%$ of preterm early neonatal deaths (table III). The early neonatal mortality in this group (27.5 per 1000$)$

TABLE VIII-Indications for elective preterm delivery: liveborn infants without lethal deformity

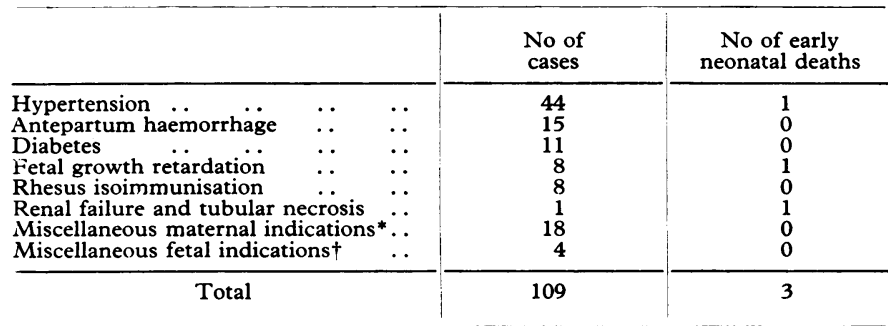

*Pelvic tumour, haemophilia, ulcerative colitis, renal disease, static weight, previous pelvic surgery, errors in gestational age, etc.

TABLE VI-Spontaneous preterm labour associated with maternal or fetal disorders: number of liveborn infants without lethal deformity and number of early neonatal deaths (in parentheses) according to gestational age and birth weight

\begin{tabular}{|c|c|c|c|c|c|c|c|c|c|c|}
\hline \multirow{2}{*}{$\begin{array}{c}\text { Gestational } \\
\text { age } \\
\text { (weeks) }\end{array}$} & \multirow[b]{2}{*}{-999} & \multirow[b]{2}{*}{-1249} & \multirow[b]{2}{*}{-1499} & \multicolumn{2}{|c|}{ Birth weight ( $g$ ) } & \multirow[b]{2}{*}{-2249} & \multirow[b]{2}{*}{-2449} & \multirow[b]{2}{*}{$\geqslant 2500$} & \multirow{2}{*}{$\begin{array}{c}\text { No of } \\
\text { infants }\end{array}$} & \multirow{2}{*}{$\begin{array}{l}\text { No of } \\
\text { deaths }\end{array}$} \\
\hline & & & & -1749 & -1999 & & & & & \\
\hline $\begin{array}{c}26-27 \\
28-29 \\
30-31 \\
32-33 \\
34-35 \\
36\end{array}$ & $\begin{array}{l}3(1) \\
1(1)\end{array}$ & $\begin{array}{l}2(1) \\
1 \\
2 \\
1\end{array}$ & $\begin{array}{l}5(2) \\
3(1) \\
3(1) \\
1\end{array}$ & $\begin{array}{l}2(1) \\
3 \\
5\end{array}$ & $\begin{array}{l}2(1) \\
3 \\
7\end{array}$ & $\begin{array}{l}5 \\
3 \\
3\end{array}$ & $\begin{array}{r}2 \\
13 \\
3\end{array}$ & $\begin{array}{r}4 \\
19\end{array}$ & $\begin{array}{r}5 \\
6 \\
7 \\
16 \\
29 \\
33\end{array}$ & $\begin{array}{l}2 \\
2 \\
2 \\
3 \\
1 \\
0\end{array}$ \\
\hline No of infants & 4 & 6 & 12 & 10 & 12 & 11 & 18 & 23 & 96 & \\
\hline No of deaths & 2 & 1 & 4 & 1 & 1 & 1 & 0 & 0 & & 10 \\
\hline
\end{tabular}

TABLE VII-Spontaneous preterm labour in twin pregnancy: number of liveborn infants without lethal deformity and number of early neonatal deaths (in parentheses) according to gestational age and birth weight

\begin{tabular}{|c|c|c|c|c|c|c|c|c|c|c|c|}
\hline \multirow{2}{*}{$\begin{array}{c}\text { Gestational } \\
\text { age } \\
\text { (weeks) }\end{array}$} & \multicolumn{9}{|c|}{ Birth weight (g) } & \multirow{2}{*}{$\begin{array}{c}\text { No of } \\
\text { infants }\end{array}$} & \multirow{2}{*}{$\begin{array}{l}\text { No of } \\
\text { deaths }\end{array}$} \\
\hline & $<750$ & -999 & -1249 & -1499 & -1749 & -1999 & -2249 & -2449 & $\geqslant 2500$ & & \\
\hline $\begin{array}{c}26-27 \\
28-29 \\
30-31 \\
32-33 \\
34-35 \\
36\end{array}$ & $2(2)$ & $1(1)$ & $6(3)$ & $\begin{array}{l}3(2) \\
2(1)\end{array}$ & $\begin{array}{l}1 \\
2\end{array}$ & $\begin{array}{l}8 \\
5 \\
1\end{array}$ & $\begin{array}{l}1 \\
9 \\
9\end{array}$ & $\begin{array}{l}1 \\
6 \\
5\end{array}$ & $\begin{array}{r}3 \\
11\end{array}$ & $\begin{array}{r}3 \\
9 \\
3 \\
12 \\
23 \\
26\end{array}$ & $\begin{array}{l}3 \\
5 \\
1 \\
0 \\
0 \\
0\end{array}$ \\
\hline No of infants & 2 & 1 & 6 & 5 & 3 & 14 & 19 & 12 & 14 & 76 & \\
\hline No of deaths & 2 & 1 & 3 & 3 & 0 & 0 & 0 & 0 & 0 & & 9 \\
\hline
\end{tabular}


TABLE IX-Elective preterm delivery: number of liveborn infants without lethal deformity and number of early neonatal deaths (in parentheses) according to gestational age and birth weight

\begin{tabular}{|c|c|c|c|c|c|c|c|c|c|c|c|}
\hline \multirow{2}{*}{$\begin{array}{c}\text { Gestational } \\
\text { age } \\
\text { (weeks) }\end{array}$} & \multicolumn{9}{|c|}{ Birth weight (g) } & \multirow{2}{*}{$\begin{array}{l}\text { No of } \\
\text { infants }\end{array}$} & \multirow{2}{*}{$\begin{array}{l}\text { No of } \\
\text { deaths }\end{array}$} \\
\hline & $<750$ & -999 & -1249 & -1499 & -1749 & -1999 & -2249 & -2449 & $\geqslant 2500$ & & \\
\hline $\begin{array}{c}28-29 \\
30-31 \\
32-33 \\
34-35 \\
36\end{array}$ & 1 & 1 & $\begin{array}{l}2(1) \\
1 \\
1\end{array}$ & $\begin{array}{l}3(1) \\
2 \\
4\end{array}$ & $\begin{array}{l}2 \\
2 \\
3\end{array}$ & $\begin{array}{l}1 \\
3 \\
3(1)\end{array}$ & $\begin{array}{r}2 \\
11 \\
5\end{array}$ & $\begin{array}{r}6 \\
17\end{array}$ & $\begin{array}{l}11 \\
28\end{array}$ & $\begin{array}{r}3 \\
5 \\
7 \\
38 \\
56\end{array}$ & $\begin{array}{l}1 \\
1 \\
0 \\
0 \\
1\end{array}$ \\
\hline No of infants & 1 & 1 & 4 & 9 & 7 & 7 & 18 & 23 & 39 & 109 & \\
\hline No of deaths & 0 & 0 & 1 & 1 & 0 & 1 & 0 & 0 & 0 & & 3 \\
\hline
\end{tabular}

was considerably lower than that in any other group of preterm delivery, although in many cases obstetric intervention was performed because of complications similar to those associated with spontaneous preterm labour. Gestational ages and birth weights for all cases are shown in table IX. Elective caesarean section (57 cases) was performed only after 28 weeks' gestation. Of the two infants in this group who died within a week of birth one was delivered at 36 weeks' gestation because of intrauterine growth retardation; he weighed less than the 5th percentile and died from hyaline membrane disease and intraventricular haemorrhage. The second infant was delivered at 30-31 weeks because of severe maternal pre-eclampsia and died of Escherichia coli septicaemia. Only one early neonatal death was associated with $\mathbf{5 2}$ cases of induction of labour before 37 weeks' gestation. The mother had acute renal failure at 29 weeks and the infant died of hyaline membrane disease.

\section{Discussion}

Information on the influence of gestational age on perinatal mortality is limited. ${ }^{1}$ Data for this country are derived almost exclusively from the British Perinatal Mortality Survey ${ }^{16}$ and, more recently, from the British Births Survey, ${ }^{17}$ which did not differentiate between the various types of preterm delivery and emphasised birth weight more than gestational age. Yet gestational age, although often difficult to assess, may be more important for perinatal mortality than birth weight, ${ }^{16}$ and many infants of low birth weight are not preterm but growth retarded. ${ }^{91516}$ We therefore examined the effect on mortality of both gestational age and birth weight in preterm infants in relation to the probable reason for their early birth. We also excluded all cases of lethal congenital abnormality from our analysis since preterm delivery would not, of course, influence mortality from this cause, which accounted for about one-third of perinatal deaths.

One out of every 20 infants born at the John Radcliffe Hospital, Oxford, during 1973 and 1974 had a gestational age of less than 37 weeks. Although they represented only $5 \cdot 1 \%$ of all births $(4.2 \%$ if a correction is made for twins and lethal congenital malformations), these infants were responsible for $85 \%$ of all early neonatal deaths not due to lethal deformity. Preterm infants born alive had a chance of survival 120 times lower than that of infants born later in gestation.

When preterm labour was spontaneous, whether or not it was associated with fetal or maternal disorders or with twins, the early neonatal mortality rate was high, ranging from 81 to 118 per 1000 (table III). Yet when preterm delivery was due to deliberate obstetric intervention the neonatal death rate was relatively low $(27.5$ per 1000$)$. Although at least part of the explanation may be that elective preterm delivery tends to occur later in pregnancy than spontaneous preterm labour, spontaneous preterm labour and unexpected delivery may also influence the duration and severity of intrapartum asphyxia, which contributes to the high perinatal mortality in these infants. ${ }^{18}$

The early neonatal mortality rate was closely linked to both gestational age and weight at birth, particularly when preterm labour was spontaneous and of unknown cause or was associated with twins. In twins all early neonatal deaths occurred before 32 weeks in infants weighing less than $1500 \mathrm{~g}$. In single pregnancies the major early neonatal loss occurred early in gestation: twothirds of all deaths were before the 28th week, when none of the infants survived, whereas the risk decreased considerably thereafter. Postponing delivery in twins to 32 weeks and in singletons to 28 weeks would obviously considerably reduce early neonatal mortality in our community. This emphasises the importance of preventing or stopping preterm labour at this crucial stage of pregnancy. It is, however, often not possible to prevent impending delivery once labour has started. Of the 24 patients admitted in preterm labour of unknown aetiology and who went on to deliver before the 32 nd week 12 already had a cervical dilatation of $4 \mathrm{cms}$ or more on admission. Of the remaining 12 patients all but two delivered within 48 hours of admission.

Most early neonatal deaths associated with this type of preterm delivery therefore seem to be unavoidable on admission. Yet these were potentially normal infants born of obstetrically normal mothers who died because they were born too soon. Two-thirds died of hyaline membrane disease. Although some of these deaths may possibly be avoided by giving the mother glucocorticoids, ${ }^{19}$ one-third were extremely immature and weighed less than $700 \mathrm{~g}$. Efforts must therefore be aimed at predicting this type of preterm labour, which seems to have no forewarning signs, so that, given appropriate prophylactic treatment, prevention may be possible.

This work was supported by grants G $971 / 809 / \mathrm{C}$ and G 974/185/C from the Medical Research Council.

\section{References}

1 Alberman, E, Clinics in Obstetrics and Gynaecology, 1974, 1, 1.

2 Expert Group on Prematurity. Final Report, Technical Report Series No 27. Geneva, World Health Organisation, 1950.

3 Public Health Aspects of Low Birthweight, Technical Report Series, 1961, No 217. World Health Organisation, Geneva.

4 Prevention of Perinatal Morbidity and Mortality, World Health Organisation, Public Health Papers, No 42, 1969.

5 Committee on Fetus and Newborn, Pediatrics, 1967, 39, 935.

6 Working Party to discuss Nomenclature based on Gestational Age and Birthweight, Archives of Disease in Childhood, 1970, 45, 730.

${ }^{7}$ Recommendations of the World Health Organisation Consultation on Methodology of Reporting and Analysis of Perinatal and Maternal Morbidity and Mortality, Bristol, 25-27 September 1972.

${ }^{8}$ Baird, D, Fournal of Pediatrics, 1964, 65, 909.

Abramowicz, M, and Kass, E H, New England fournal of Medicine, 1966, 274, 878.

${ }^{10}$ Usher, R, McLean, F, and Scott, K E, Pediatric Clinics of North America, $1966,13,835$.

${ }^{11}$ Farr, V, et al, Developmental Medicine and Child Neurology, 1966, 8, 807.

12 Dubowitz, L M S, Dubowitz, V, and Goldberg, C G, Fournal of Pediatrics, 1970, 77, 1.

13 Babson, S G, Behrman, R E, and Lessel, R, Pediatrics, 1970, 45, 937.

14 Tanner, J M, and Thomson, A M, Archives of Disease in Childhood, $1970,45,566$.

15 Campbell, S, Clinics in Obstetrics and Gynaecology, 1974, 1, 41.

${ }_{16}$ Butler, N R, and Alberman, E, Perinatal Problems. London, Butterworths, 1969.

17 Chamberlain, R, British Births 1970, p 235. London, Heinemann, 1975.

18 Roberton, N R C, and Tizard, J P M, British Medical fournal, 1975, 3, 271.

19 Liggins, G C, and Howie, R N, Pediatrics, 1972, 50, 515. 